\title{
Bertso-eskolak: alderdi sozio-emozionalaren garrantzia ahalduntze prozesuan
}

\section{Verse Schools: The Importance of Socio-emotional Aspects in Empowerment Process}

\author{
VANESA FERnÁndez RodRíGUeZ \\ Euskal Herriko Unibertsitatea \\ vfernandez034@ikasle.ehu.eus \\ Maria Teresa Vizcarra Morales \\ Euskal Herriko Unibertsitatea \\ mariate.bizkarra@ehu.eus \\ Amaia Alvarez-Uria \\ Euskal Herriko Unibertsitatea \\ amaia.au@ehu.eus \\ Recibido: abril de 2021. Aceptado: mayo de 2021.
}

Laburpena: Hasierako bertsolaritzaren irakaskuntza teknikaren jabekuntzan zentratzen zen eta tradizionalki bertsolaritza gizonen jarduera izan da (Larrañaga 2013: 41). Mende aldaketarekin batera ordea, gizartean aldaketak egon dira, eta aldaketa horiek bertsolaritzaren sisteman eta ikaskuntzan isla eta eragina izan dituzte. Lan honetan egungo emakume bertsolari eta irakasleek bertso-eskoletan eta hezkuntza arautuan zer-nolako metodologia erabiltzen duten eta alderdi sozio-emozionala eta ahalduntze prozesua zelan kudeatzen dituzten ezagutu nahi izan dugu, euren diskurtso eta praktikei arreta jarriz. Horretarako 10 elkarrizketa sakon eta 16 behaketa egin dira. Emaitzen artean ikus daiteke adimen emozionalaren lanketa egiten dela, bai pertsonala bai taldekoa; genero perspektiba esparru formal eta ez formaletan txertatu dela, eta irakasleak ikasle guztiak ahalduntzen saiatzen direla, ikasleak bide horretan agente aktibo bihurtze aldera.

Hitz gakoak: adimen emozionala, trebetasun pertsonal eta sozialak, agentzia, ahalduntzea, bertsolaritza. 


\begin{abstract}
The teaching of bertsolaritza focused on acquisition of the technique and traditionally bertsolaritza has been an activity of men (Larrañaga 2013: 41). However, there have been changes in society, which have influenced the system of bertsolaritza and teach methods. In this work we wanted to know what kind of methodology current women bertsolaris and teachers use in verse schools and formal education and how they manage the Socio-emotional aspect and the empowerment process, focusing on their discourses and practices. To this end, 10 in-depth interviews and 16 observations were made. Among the results it can be seen the development of emotional intelligence, both personal and group; the gender perspective has been embedded in both formal and non-formal education, and teachers are trying to empower all students to become active agents.
\end{abstract}

Key words: emotional intelligence, personal and social skills, agency, empowerment, oral basque poetry.

\title{
I.- SARRERA
}

Aurreko mendearen amaieran bertsolaritzaren irakaskuntza tradizionala alde teknikoan eta bat-bateko sormenean zentratu zen, bertsoen ekoizpenean zehazki, eta bertsolari identitatearen edo talde izaeraren eraikuntzarako beharrezkoa den lanketa sozio-emozionalak ez zuen lekurik izan garai hartan (Alberdi 2015; Lasarte + Fernández + Álvarez-Uria + Gómez 2019: 508).

Azken hamarkadetan ordea, gizartean gertatu diren aldaketek eragina izan dute bertsolaritzaren garapenean (Artetxe, 2019:257), eta horrekin batera, bertsolaritzaren ikaskuntza-irakaskuntzan. Era berean, emakume bertsolarien ibilbidean hainbat mugarri aipatu dira azken ikerlanetan eta lan horietan agertzen diren esperientziek eta testigantzek argia eman diete emakumeek bertsolaritzaren sisteman bertsolari eta irakasle gisa sartzean eta jardutean izan dituzten bizipen eta jokaerei (Alberdi 2015; Alberdi 2019; Lasarte + Fernández + Alvarez-Uria + Gómez-Pintado 2019: 508). Izan ere, sozialki diskriminatuta dagoen kolektibo honek bere eskubideak eta aukera berdintasuna lortzeko jardun behar izan du bidea urratzen azken urteotan eta horrek paradigma aldaketa ekarri du mende berriarekin batera.

Hezkuntzara eramaten badugu lanketa hori, eta irakaskuntzara zehazki, edukien transmisio hutsetik harago joan behar garela ulertuko da. Izan ere, ikaskuntza-irakaskuntzan berebiziko garrantzia dute honako ezaugarri hauek: ikasleak bere burua ikasteko eta esku-hartzeko gai ikusteak, taldearen partaide sentitzeak eta taldekideen arteko harremanak zaintzeak. Hortaz, alde batetik, irakasle lanean adimen emozionala jorratzeak berebiziko garrantzia du; emozioen kudeaketa bertsolari(gai)ak egin behar duen prozesu kontzientea da eta hor sar ditzakegu adimen pertsonala eta sozialaren ezaugarriak. Bestetik, perspektiba feministaz hitz egitea ezinbestekoa da egungo bertsolaritza ulertzeko, azken urteetan emakume (bertsolari) asko feminismoarekin identifikatu dira eta (Alberdi 2019:141). Mende berriarekin batera emakume bertsolariak 
kontzientzia feministaren hedapenean murgilduta ageri dira (Esteban 2019: 303); teoria zein praktika feministak bertsolaritzaren egunerokotasunean aztarna uzten hasi dira.

\subsection{Adimen emozionala}

Hezkuntza eremuan adimen emozionalaren gaia leku garrantzitsua hartzen joan da azken 40 urteetan zehar. Izan ere, ikasleen alde emozionalaren zaintza XX. mendearen hezkuntza eremuko ezagutzaren eraikuntzan garrantzitsua izan da, hau da, adimen emozionalak curriculum akademikoan ezagutza eskuratzeko leku ahaltsua izan du (Lanku 2008: 31). Zientziak emozioen oinarrizko kudeaketa bizitzarako jokaera, gaitasun edo ezagutza garrantzitsua dela egiaztatu du; horrekin batera nabarmendu du orain dela urte batzuk arte ezagutza akademikoari soilik eman zaiola indarra (Bisquerra 2011:17).

Adimen emozionala kontzeptua Michael Beldochek 1964. urtean publikatutako artikulu batean agertu zen lehenengo aldiz. Howard Gardnerrek 1983. urtean Frames of Mind: The Theory of Multiple Intelligences aurkeztu zuen, eta hainbat adimenen artean adimen intrapertsonala (zeure burua ulertu, zure sentimenduak, beldurrak eta motibazioak aintzat hartu) eta adimen interpertsonala definitu zituen, adimen emozionalarekin erlazionatutakoak. Geroago, autore batzuk haien lanetan adimen horiei buruz hitz egin dute, baina Daniel Golemanen Emotional Intelligence liburua argitaratzearekin (1996) izan zuen adimen emozionalaren kontzeptuak zabalkunde handiena (Haardep + Gowda 2019: 990). Horrela, Salovey eta Mayerren arabera (1990:189) adimen emozionalari esker gure pentsamenduak eta ekintzak bideratze aldera, sentimenduak eta emozioak detektatzeko eta kudeatzeko trebetasuna gara daiteke.

Ildo horretan, inteligentzia emozionala norberaren eta besteen emozioez jabetzeko eta emozioak erregulatzeko gaitasuna dela aipatzen du. Hots, norberak bere emozioen erregulazioa lortzeko kontzientzia emozionala ezinbestekoa dela defendatzen du (Fragoso 2015: 120). Auto-erregulazio emozionala inpultsibotasun eta errepresioaren erdian kokatuko genuke, izan ere, mutur horietako edozeinetan egotea kaltegarria izango litzateke pertsonarentzat. Golemanek dio (in Bisquerra, 2003: 19) adimen emozionalak honako ezaugarri hauek dituela:

- Norberaren emozioak ezagutzea.

- Emozioak kudeatzea.

- Nork bere burua motibatzea.

- Besteen emozioak ezagutzea, haiekiko enpatia izatea.

- Beste pertsonekin harreman positiboak ezartzea, trebetasun sozialak garatzea.

Lehenengo hiru dimentsioak auto-erregulazioarekin lotuta daude; izan ere, gure sentimenduak ezagutzea, kudeatzea eta geure burua motibatzea autoezagutzari erreferentzia egiten dioten faktoreak dira. Gardnerrek (1993) adimen intrapertsonal gisa bataiatu zuen gaitasun multzo hau, baina trebetasun emozional 
pertsonalak ere deitu izan dira. Azken bi dimentsio horiek, ordea, enpatiak eta trebetasun sozialek, adimen sozialarekin harremana dutela dio. Zehazki, beste pertsonak ulertzeko gaitasuna da, giza harremanak hobetzeko. Adimen emozionala duen pertsonak pertsonen arteko desberdintasun indibidualak behatu eta onartzen ditu, pertsonen sentimenduak, hausnarketak eta motibazioak ulertzen ditu, enpatia eta elkarrekintza erabiltzen ditu horretarako.

Aipatu den bezala, adimen emozionalean bi motatako adimen bereizten dira: pertsonala eta soziala (Gardner 1993; Goleman 1996). Adimen pertsonala adimen intrapertsonalarekin bat egiten duena da, eta adimen sozialari beste egile batzuek adimen interpertsonala deitu izan diote (Bisquerra 2003: 15; Losada 2018: 9). Bi adimenak garrantzitsuak dira pertsonaren garapena orekatua izan dadin; izan ere, pertsonak bere buruaz duen ezagutzak harreman sozialetan eragin handia izango du.

\subsection{Emozioen kudeaketa bertsolaritzan}

Emozioen kudeaketa ikaskuntza-prozesu etengabea da eta konpetentzia emozionalen garapenean eta giza garapena sustatzean oinarritzen da, horretarako bizitzarako erremintak sortu behar dira eta ongizate pertsonala eta soziala handitu (Bisquerra, 2003: 8).

Bertsolari hitza aipatzerakoan hizkuntzan eta musikan pentsatzen dugu, baina bertsolariak bertsolaritzan partaidetza aktiboa duenean bere adierazpenean izaera pertsonala eta soziala islatuko ditu (Lanku 2008: 57). Hortaz, Bertsolaritza Curriculumean (2008) lana argitaratu zutenean egileek aipatu zuten trebetasun pertsonal eta sozial jakin batzuk beharrezkoak direla bertsolari izateko. Horrela adierazten dituzte trebetasun sozial eta pertsonal horiek:

Jendaurreko inprobisazioa izaki, [bat-bateko bertsolaritzak] trebetasun ugari eskatzen ditu: norberareganako konfiantza, besteen lekuan jartzen jakin eta besteak ulertzea, edozein egoeratara egokitzea, norberaren emozioen erregulazioa, jendaurrekotasuna, komunikatzaile ona izatea, oroimena, gauzak hainbat eratara adierazten jakitea, ikuspuntu desberdinak erabiltzeko gaitasuna... (Lanku 2008: 57).

Uxue Alberdik puntu honetaz hitz egitean bertsolariak 'emozioen termometroa' aktibatuta izan behar duela aipatzen du, hau da, entzuleen sentimenduak kontuan izan behar ditu eta bertsoa sortzen duenean hartzaileentzat kantatu (Lasarte + Alvarez-Uria + Ugalde + Lekue + Martinez 2016:67).

Ildo honetan baiezta daiteke alde emozionalaren lanketa ezinbestekoa dela oholtzan ahal bezain ondo egoteko eta txapelketetan modu emankor, egoki eta orekatuan parte hartzeko. Bertsolaritzaren teknika ezagutzea inportantea da bertsoak kantatzeko, bestela esanda, errimak, doinuak eta neurriak ezagutu eta barneratu behar dira (Amuriza 1982:11-172). Gainera eduki aldetik, diskurtso borobilak eta ideia landuak osatu behar dira. Hala ere, zenbaiten ustez bertsolaritzaren sisteman zerbaitek huts egin du urte batzuetan zehar, alde teknikoa 
bakarrik hartzen baitzen kontuan bertsolaritzaren irakaskuntzan. Sistema hori jaso zuten pertsona batzuek asko hausnartu dute horren inguruan, eta orain bertsolaritzaren irakaskuntza sistema aldatzen ari dira (Lasarte + Álvarez-Uria + Ugalde + Lekue + Martínez 2016:151). Izan ere, ikasleen alde sozio-emozionala kontuan hartu eta zainduko da ikaskuntza prozesu horretan Bertsozale Elkartearen azken materialak eta curriculum-proposamena kontuan izanik. Zehazki, landu beharreko alderdiak hurrengo irudian argi agertzen dira (1.irudia), bakoitzari zor zaion garrantzia emanez:

I. IRUDIA. BERTSOGINTZAREN IKUSPEGI BATERATZAILEA (LANKU 2008: 20)

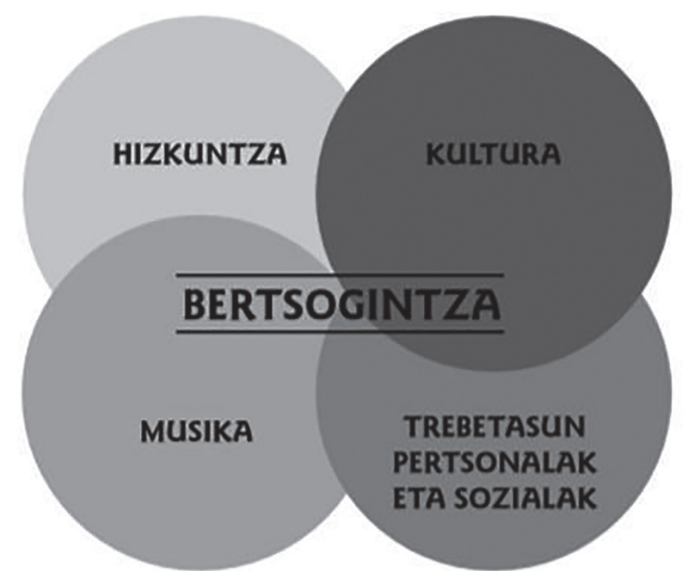

\subsubsection{Bertsolari(gai)aren trebetasun pertsonalak}

Lehen aipatu lez, trebetasun pertsonalen multzoan norberaren emozioen ezagutza, emozioen kudeaketa eta motibazioa sar daitezke. Jendaurrekotasunak exijitzen duen bat-bateko sormen jarduera egoki egin nahi bada, autoestimu positiboa izan beharko du bertsolariak (Alberdi 2015; Lanku 2008: 60; Lasarte + Álvarez-Uria + Ugalde + Lekue + Martinez 2016: 152).

Hortaz, ikasle bakoitzak momentu zehatz batean sentitzen eta esperimentatzen dituen emozioak identifikatzea lehenengo pausoa izango da bide horretan. Bestela esanda, lehenengo faseak kontziente izatea eskatzen du. Kontzientziazio momentu horretan ezinbestekoa da emozio horiek bideratzen jakitea, eta modu orekatuan jokatu beharko litzateke. Hori da bigarren urratsa. Baina gure emozioekin bat egin ondoren, salto handia egiten dugu auto-motibaziora ailegatzeko bidean. Fase honetan, pertsona baikorrak, motibatuak eta haien emozioen arduradunak izan behar dugu eta arazoei modu osasuntsu eta eraginkorrean aurre egiten dieten pertsonak izatera heldu. 
Motibazioa pertsonen barruko egoera bat da eta jarrera bideratzen du, aktibatze eta mantentze prozesu batean. Motibazioak, ikasleak ekintza aurrera eramateko dituen gaitasunetan sinestea ahalbidetzen du eta berak ekintzaren erantzukizuna duela (Printich + De Groot 1990: 33).

Bertsolaritzaren sisteman zentratuz, Lasarte et al.-ek (2016) eginiko emakume bertsolariei buruzko ikerketan aipatzen dute neskek autoestimu falta izan dutela eta ez da harritzekoa testuingurua alde izan ez dutela kontuan izanik. Ikerketa horretan emakumezko bertsolarien oholtzarako jauzian eragina izan zuten faktoreak adierazi zituzten elkarrizketatutako askok, eta faktore horien artean segurtasuna, konfiantza, agentzia eta emozioen lanketa haiek jasotako bertsolaritzaren irakaskuntzan leku txikia izan zutela ondorioztatu zuten. «Arrunta da emakumeak ez ikustea bere burua gauza askotarako gai, batez ere, publikoaren aurrean egin behar diren ekintzetan» (Soroa 2010: 31 ).

Izan ere, Zubiri et al.-en (2019) ikerketan irakurri dezakegun moduan emakumeak sozialki eta tradizionalki zapaldutako kolektibo bat izateak eta horren ondorioz eremu publikoa historian zehar debekatuta egon izanak bere eragina izan du publikoaren aurrean bat-batean aritzeko jardueran:

\begin{abstract}
Baldintza sozialek eragozpen handirik sortzen ez dutenean (...) bertso-eskoletan 18 urtetik beherakoen artean (...) parekidetasuna askoz hurbilago dagoela. Aitzitik, jatorri soziala duen desberdinkeriak bereziki estutzen duenean (nerabezaroan helduarorako trantsizioa egiten denean; ahotsa publikoki hartzen denean; komunikazioa egikaritzeko entzulearekiko gutxieneko konplizitatea, hurbiltasuna eta onarpena bilatzea ezinbestekoa denean), handitu egiten da genero arloko desberdinkeria (2019: 147).
\end{abstract}

Aipatutakoak kontuan izanda, adituek oso ondo ezagutzen dute etorkizuneko bertsolariek arreta non jarri behar duten norbanakoaren eta talde osoaren ongizatea lortzeko. Bertsolaritzaren irakaskuntzan teknikaren eta emozioaren arteko bateratzea egon beharko luke eta, jarraian ikusiko dugun bezala, norabide horretan urratsak ematen hasi dira azken urteotan.

\title{
1.2.2. Bertsolari(gai)aren trebetasun sozialak
}

Goleman-en (1996) hitzak berreskuratuz, konpetentzia sozialari dagokio enpatia izatea eta beste pertsonekin harreman positiboak ezartzea (Alviárez+Pérez 2009:6) Gainera, multzo horretan sar ditzakegu emozionalki inteligente direnak. Izan ere kapazak dira lagunak egiteko eta mantentzeko, ondo egokitzen dira edozein egoera sozialetan eta erremintak dituzte arazoei edo gatazkei aurre egiteko.

Enpatiak besteen emozioak irakurtzean, ezagutzean, ulertzean eta haiekin konektatzean datza. Besteen ikuspuntua ez ezik, gertaera batean bizi diren emozioak ere ulertzea da. Enpatiari kontzientzia soziala ere deitu izan zaio. Ohiko definizioaren arabera bestearen tokian jartzeko gaitasuna da. 
Trebetasun sozialen garapena oso baliagarria da gure bizitzako hainbat arlotan (Betancourth, Zambrano + Ceballos + Benavides + Villota 2017:134), gure ingurunearekin hobeto erlazionatzeko aukera ematen baitigu. Hitzik gabeko komunikazioa (jarrera, ahotsaren tonua edo intentsitatea, begirada, keinuak, eta abar) oso garrantzitsua da pertsonen arteko harremanetan (Flores + García + Calsina + Yapuchura 2016: 8). Pertsona enpatiko bat gai izango da horrelako seinaleak irakurtzeko, eta, aldi berean, entzuteko ahalmena garatuko du (Bisquerra 2011: 67-68).

Bertsolaritzaren alorrera bueltatuz eta trebetasun sozialei dagokienez, esan bezala, jendaurrekotasunaren lanketak garrantzi handia du (Lanku 2008: 58). Kontzentrazioa mantentzea, diskurtso koherentea egitea, publikoaren erantzuna kudeatzea, edo oholtza gainean bertsolarien urduritasuna murriztea trebetasun sozialei esker egoki kudeatzen jakingo du bertsolariak. Bertso-eskoletan eta hezkuntza arautuan lanketa horiek egin arren, zaila da aurreikustea egoera errealean egon arte gertatuko dena (Lasarte + Álvarez-Uria + Ugalde + Lekue + Martinez 2016: 141).

Puntu honetan landu beharreko beste gaietako bat talde-lana izango litzateke. Ez da kasualitatea kontzeptu hau Bertsolaritzaren Curriculuma Lehen Hezkuntzan lanean zenbait aldiz azpimarratzea, (zazpi aldiz zehazki). Bertsolari izatea prozesu autonomoa da eta bertsolariak teknikaren ezagutza, sormenaren lanketa eta bere diskurtsoaren eraikuntza osatu behar ditu, baina ezin dugu ahaztu testuinguruaren eragina eta, honekin batera, kideen laguntzaz eta publikoarentzat bat-batean kantatzen duela.

Bertsolaritza talde lana bezala ulertu behar dugu, hainbat pertsona kualifikatuk dihardutelako horretan: antolatzaileak, eragileak, epaileak, sortzaileak, gai-jartzaileak, eta entzuleak, besteak beste (Lanku 2008: 58; Lasarte + Vizcarra + Perales + Fernández 2020: 261; Sarasua 2007: 44). Hortaz, lankidetzak pisu handia du bertsogintzan. Bertsolariak banaka eraikitzen duen bertsotik bertso saio osoa elkarlanean kantatzeraino egongo da presente alderdi soziala. Egoera kontuan hartu behar du beti bertsolariak, mezu egokiak erabili behar ditu edozein testuingurutan eta entzulea harritu edo hunkitu behar du. Bakoitzaren ikuspuntua zein den ahaztu gabe besteena ulertzeko gai izan behar da bertsotan egiteko, hori da konpetentzia soziala adieraztea.

\subsection{Agentzia eta ahalduntzea}

«Emakume bertsolariak betidanik izan dira gurean» (Lujanbio 2019: 78). Baina bat-bateko bertsolaritza plazagizonena izan da historikoki eta emakumeek haien presentzia eta parte-hartzea bermatzeko bidea egiten ibili behar izan dira, eta oraindik horretan dihardute (Lasarte + Fernández + Alvarez-Uria + Gómez-Pintado 2019: 511).

Egungo bertsolaritza gizonen jarduera izatetik, emakumeen jarduera ere izatera igaro da (Larrañaga 2013: 41). Hortaz, emakume idazle ingelesei begira Elaine Showalterrek argitaratu zuen A Literature of Their Own lanean egin zuen sailkapena bertsolaritzara ekarrita, hainbat fasetan kokatu dezakegu emakume 
bertsolarien sorkuntza: femeninoa edo feminine (gizonen eredua jarraitzen dute), feminista edo feminist (haien eskubideak aldarrikatzen dituzte), eta emakumearena edo female (norberaren estetika aurkitzea dute xede) (Moi 1989: 117-123).

Bertsoaren munduan ordea, ez dira kronologikoki bata bestearen atzetik gertatu, izan ere, hirurak aldi berean gertatu direla esan genezake, baina egun nagusiki idazkera propioa sortzen ari direla egiaztatu daiteke, haien barruko ahotsaren bila dabiltzalako (Alberdi 2019; Lasarte + Ugalde + Alvarez-Uria + Martinez 2019: 57).

Genero perspektiba kontuan hartuta, azken bi hamarkadetan aldaketa handia egon da bertsolaritzan (Alberdi 2019; Artetxe 2019:257). Emakume bertsolarien ibilbidea ulertzeko bi kontzeptu garrantzitsu kontuan izan behar dira: ahalduntzea eta agentzia.

Ahalduntze hitza aipatzen dugunean, botere harremanei buruz hitz egiten dugu, eta hauek ezartzen duten menderakuntza egoerari buruz. Zehazki, botere eta kontrol gabezia dutenek menpeko egoera atzean utz dezaten, existitzen diren botere-harremanak kolokan jartzearen premiaz hitz egiten dugu (Lasarte + Ugalde + Alvarez-Uria + Martinez 2019: 41). Horrela, botere pertsonala lortu behar du botere-gabetuak eta horretarako aurretik subordinazio egoeran dagoela jabetu behar da. Honi buruz hausnartzea izango da lehenengo urratsa. Bere zapalkuntza egoeraz kontzientzia hartu behar du eta konturatu ez dela berari bakarrik gertatzen zaion zerbait, kolektibo baten parte izatearen ondoriozko egiturazko biolentzia dela baizik. Geroago, lortu duen botere pertsonala sozializatuko du, barneko eta kanpoko esperientziak partekatuz eta integratuz. Azkenik aldaketarako botereari eta politika eraginari buruz hitz egingo da komunitate horretan (Lasarte + Vizcarra + Perales + Fernández 2020: 253).

Ahalduntzea boterea irabaztearekin erlazionatuta dago; agentzia ordea, objektu izatetik subjektu izatera pasatzen denean gertatzen dena da (Lasarte + Ugalde + Alvarez-Uria + Martinez 2019:41). Sherry Ortner antropologoak esaten du agentzia terminoak pertsona batek egiturazko baldintzak aktiboki aldatzeko duen gaitasunarekin zerikusia duela. Honela, Agentzia ekintza sozial eta indibidual lez uler daiteke (Lasarte + Vizcarra + Perales + Fernández 2020: 253). Erlazio estua du subertsio, erresistentzia eta negoziaziorekin. Hortaz, ahalduntze bide horretan ezinbestekoa da lehenengo agentzia eskuratzea.

Lehen esan bezala, azken urteotan bertsolaritza aldaketa garaian dago, eta genero ikuspegia kontuan hartuta, emakume bertsolariek burututako zenbait ekimenei esker izan dela baiezta daiteke, neurri handi batean. Ildo honetan, Miren Artetxek (2019) honako ideia hau aipatzen du:

Gizartean akademia eta mugimendu feministari esker maila diskurtsiboan zein praktikoan egin diren aldaketez gain, besteak beste emakume bertsolariek haien beharrei erantzuteko modu formal zein informalagoan, kontziente zein inkontzienteagoan, modu indibidual zein kolektiboagoan garatutako hainbat ekimeni esker izan da aldaketa, hain zuzen ere (p.259). 
Honela, zenbait mugarri aipatzen ditu autore honek: lehen erreferenteen ekarpena, emakume bertsolarien saretzea eta teorizazio zein praktika feministak bertsolaritzara hurbiltzea (Artetxe, 2019: 259-264).

Emakume bertsolariak zenbait topaketetan elkartu dira eta jabekuntza prozesu batean daude. Topaketa horietan, generoa bertsoaren munduan lantzeko ekimenak sortu dituzte, genero ikuspegia eta feminismoa bertsolaritzan txertatzeko, pertsonalaren eta politikoaren arteko loturak eginez eta haien kontzientzia feminista esnatuz.

Azken urte hauetan emakume bertsolariek eman dituzten pausoak nekez uler litezke Bertsozale Elkarteak parekidetasunaren alde garatu duen zeregina kontuan hartuko ez bagenu. 2008an, Genero Taldea sortu zen eta haren asmoa parekidetasuna suspertzea izan zen, bai bertsogintzan, bai jarduera eta proiektuen antolaketan, egituran, funtzionamenduan eta elkartearen harremanetan.

Lehendakaritza berria du Bertsozale Elkarteak 2018tik eta zortzikoteak genero ikuspegia funtsezkoa dela uste du. Bertsozale elkartea sustapenaz arduratzen da, eta eremu askorekin du harremana. Hortaz, ezinbestekoa da gizonemakumeen botere harremanak orekatzea, eredu tradizionalistatik alde egiteko. Baliagarria da eta izango da haien eskuhartzea elkartean barneratutako ideia batzuk aldatzeko, joera matxistak baztertzeko eta emakumeen ahalduntze bidean aldeko jarrera eta jokaera hartzeko (Lasarte + Álvarez-Uria + Ugalde + Lekue + Martinez 2016: 205).

Bertsozaleen Elkarteko Genero Taldean aurrera eraman diren ekimenak gainbegiratu ditugu eta ekintzen artean honako hauek aurkitu ditugu: gai jartzaile eta epaileen formazio tailerrak, 2014ko bertso eguna generoaren gaian oinarrituta egotea, hedabideak (telebista eta prentsa) sentsibilizatzea, bertso eskoletan eta ikastoletan bertsogintzari buruz dauden ikasmaterialak gainbegiratzea eta aholkularitza ematea genero perspektiba txertatzeko, emakume bertsolarien arteko topaketak antolatzea, eta gaiaren inguruko formazio plana egitea.

Nancy Downing-ek eta Kristin Roush-ek (1985: 706) azaldu zuten identitate feminista eraikitzeko ezinbestekoa dela kontzientziazioa eta generoaren inguruan dauden aurreiritzi eta diskriminazioei aurre egitea. Bertsolaritzari dagokionez, bide horretan hainbat lan eta hainbat estrategia markatu dira azken urteotan. Egun, hainbat esparrutan genero perspektiba txertatzen ari da bertsolaritzaren komunitatean dauden pertsona kontzientziadunek (Alberdi, 2019) eta Bertsozale Elkarteak (lehenengo genero taldearen bidez eta gero zuzendaritza berriarekin ere) bultzatuta.

Ekimen horien artean, Emakumeak plazara izeneko ekitaldia burutu zuten duela zenbait urte, edo Ez da Kasualitatea dago, 2009. urtean sortutako emakumez soilik osatutako saio musikatua (Artetxe 2019:266). Horrekin eta bestelakoekin XXI. mendean emakume sortzaileek eremu publikoan egoteko eskubidea eta beharra aldarrikatu dituzte, eta horrekin batera plazandre izena erabiltzen hasi dira zenbait bertsolari (duela oso gutxi onartu dute Euskaltzaindiaren hiztegian hitz hau), generoari buruzko hausnarketa kritikoa sustatuz eta euskal kulturak eta hizkuntzak duen ikuspegi androzentrikoa salatzeko asmoz. 
Puntu honi amaiera emateko, aipatu beharra dugu 2015ean Genero Taldeak emakume bertsolarientzako Ahalduntze Bertso-Eskola sortu zuela, non bertsotan trebatzeko lekua izateaz gain, hausnarketak eta bizipenak partekatzeko gunea da (Artetxe 2019:267).

Artikulu honetan aztertu nahi izan dugu bertso-irakasleek bertso-eskoletan eta hezkuntza arautuan zer nolako metodologiak erabiltzen dituzten eta zelan kudeatu dituzten aspektu sozio-emozionalaren zaintza eta ahalduntze eta agentzia prozesuak euren diskurtsoetan eta euren metodologietan.

\section{II.- METODOA}

Aurreko atalean azpimarratu den lez, bertso-eskoletan zein hezkuntza arautuan bertsolaritza eskoletan bai metodologietan, bai diskurtsoan nola kudeatzen den alderdi sozio-emozionala ezagutu nahi da eta bide honetan, trebetasun horiek jorratzean, gerta daitekeen ahalduntze prozesuaren berri izatea.

Esan daiteke kasu azterketa bat dela eta informazioa biltzeko erabili diren tresnak bi izan direla: elkarrizketa sakonak eta eskoletan egindako behaketa etnografikoak. Informazioa biltzeko hainbat metodo eta hainbat pertsonaren iritziak alderatuko dira eta horrela triangulazioa erabiliko da.

Hartu den ikuspegia formatiboa izan da, ezinbestekoa delako irakasleen prozesua ulertzea eta aztertutako emakumeak testuinguru horretan kokatzea; aldi berean bertsolari gisa eta irakasle gisa jokatzen duten rola ezagutzeko modu aproposena da.

\subsection{Kasu-azterketa}

Esan daiteke kasu azterketa baten aurrean gaudela emakume bertsolari hautatuek bertso-eskoletan erabiltzen dituzten metodologiak aztertuko direlako, eta hala fenomeno zehatz bat aztertu nahi delako: zehazki alderdi sozio-emozionalaren zaintza eta ahalduntze prozesuaren sustapena metodologietan eta diskurtsoetan.

Ikerketak bi fase nagusi izan ditu, alde batetik, emakume bertsolari eta irakasleen iritziak, sentimenduak eta hausnarketak jaso ditugu elkarrizketa sakonen bidez. Tresna horren bidez honako gaien inguruko informazioa jaso da: metodologia (erabiltzen diren irakaskuntza-metodoak, bai jaso zutena, bai beraiek erabiltzen dutena) eta irakaslearen estiloa (marka pertsonalak, komunikatzeko gaitasuna, motibatzeko trebetasuna, inplikazioa). Beste alde batetik, bigarren fase batean, egungo emakumeek bertso-eskoletan erabiltzen dituzten metodologiak ikusteko eta euren ekarpena aurrez aurre ezagutzeko 16 behaketa egin dira haien eskola orduetan; diskurtsoak eta praktikak bildu ditugu horrela.

Errealitate baten ulermena eta interpretazioa egin nahi izan da, hau da, emakume bertsolarien ekarpena bertsolaritzaren irakaskuntzan nolakoa den ezagutu nahi izan da. Horrek eskatu du ikertzaileak testuinguruan murgiltzea 
eta aztertutako pertsonarekin mintzatzea bertatik bertara (Rekalde + Vizcarra + Macazaga 2014: 204; Vallés 2003: 41). Hori lortu ahal izateko ikertzaileak erantzunak bilatu ditu modu sistematiko eta metodikoan (Flick 2014: 105).

\subsection{Testuinguruaren deskribapena}

Ikerketa honen testuingurua bertsolaritza da, eta esparru horren barruan, bertso-eskoletan eta hezkuntza araututako bertsolaritzari buruzko saioetan jarduten duten emakume bertsolariekin egin da. Zehazki 10 elkarrizketa sakon egin dira, eta hortxe ditugu emakume bertsolariak eta bertso-irakasleak diren elkarrizketatuak. Gure lana bertsolaritzaren ikaskuntza-irakaskuntza gertatzen den eremuetan kokatzen da.

Bertsozale Elkarteak adierazten duen bezala bertso-eskolak bertsolaritzaren ezagutzetan sakontzeko eta hizkuntzaren alde ludikoa lantzeko eratzen diren guneak dira, eta era berean, Euskal kultura modu sortzaile eta aktiboan bizitzeko aukera ematen dute. Azken urteotan hainbat ikastolatan bermatu da bertsolaritzaren irakaskuntza. Helburu horrekin 2011-2012 ikasturtean akordio bat sinatu zen Bertsozale Elkartearen eta Ikastolen Elkartearen artean, Euskal ikastolen Curriculumean bertsolaritzari dagozkion esparruak zehazten zituena.

\subsection{Partaideak eta informazioa jasotzeko estrategiak}

Ikerketa hau bertsolaritzaren testuinguruan garatu da, eta bertan hainbat audientzia kontsultatu dira, haien artean, emakume bertsolariak eta bertsoirakasleak diren emakume bertsolariak. Elkarrizketa sakonetako partaideak ikerketa honetan 10 emakume bertsolari izan dira, eta elkarrizketatuak izendatzeko honako kode hauek erabili dira: Berts1 20151112; Berts2 20151119; Berts3 20151201; Berts4 20151201; Berts5 20151203; Berts6 20151224; Berts7 20160104; Berts8 20160109; Berts9 20160115; Berts10 20160131. Elkarrizketatutako bertsolari bakoitzari zenbaki bat eman zaio eta bigarren kodea elkarrizketaren eguneko data izan da.

Behaketetako partaideak: behaketak ikastetxe arautuetan eta bertso eskoletan burutu dira, hala, 4 emakume bertsolari-irakasle eta haien taldeak behatu dira. Orotara 16 saio grabatu ziren. Behatutako irakasleak honako kode hauekin izendatu ditugu: Irakasle1, Irakasle2, Irakasle3 eta Irakasle4.

\subsection{Prozedura eta analisi tresna}

Elkarrizketa sakonak eta behaketak aurrera eraman dira eta jarraian transkribatu da material guztia. Informazioaren analisia, landa lanarekin batera, oso etapa garrantzitsua da (Goetz + Lecompte 1988: 174). Kasu honetan, jasotako informazioa analizatzea prozesu bat izan da, funtsean induktibo-deduktiboa, dinamikoa eta sistematikoa, jasotako iritzien mezua ezagutzea eskatzen duena, 
aukeratzea, sailkatzea, alderatzea eta interpretatzea. Prozesu horri esker, fenomenoak gorpuzten dituzten kontzeptu gisa ordezkatutako informazioetatik ideia nagusiak atera ahal izan dira (dimentsioak, kategoriak), baita fenomeno horietatik abiatutakoak diren kontzeptuak (azpikategoriak) ere (Coffey + Atkinson, 2003: 31-63; Rodríguez, Gil + García, 1996: 305). Horiekin guztiekin sistema kategorial bat osatu da (2. irudia). Sistema kategoriala analisia egiteko, emaitzak antolatzeko eta narrazioa eratzeko baliagarria da. Narrazioaren hari argudiatzailea eratzen da modu horretan. Sistema kategoriala eraikitzeko NVivo11 pakete digitala erabili da eta ondoren kategoria bakoitzean bildutako edukia interpretatu egin da. Metodologia eta irakasleen estiloak definituak izan dira, batez ere elkarrizketa sakonen bidez eta, aldiz, 'irakaslearen diskurtsoa hezkuntza proiektuetan' kategoria nagusiki behaketen bidez osatu da.

2. irudia: Analisi tresna, sistema kategoriala.

\begin{tabular}{|c|c|c|}
\hline Dimentsioak & Kategoriak & Indikatzaileak \\
\hline \multirow{6}{*}{$\begin{array}{l}\text { Hezkuntza-arautua eta } \\
\text { bertso-eskolen metodo- } \\
\text { logia (eskolen egoera } \\
\text { orokorra eta irakaskuntza } \\
\text { eredu proposamena) }\end{array}$} & Metodologia & $\begin{array}{l}\text { Erabiltzen diren metodoak (jaso } \\
\text { dutena eta proposatzen dutena) }\end{array}$ \\
\hline & \multirow{3}{*}{$\begin{array}{l}\text { Aspektu sozio-emo- } \\
\text { zionala banakakoa } \\
\text { (ikasle-irakasle) }\end{array}$} & $\begin{array}{l}\text { Feedback (positiboa, negatiboa, } \\
\text { zuzentzailea). Nola zuzentzen } \\
\text { duen, noiz, arazo kognitiboak, } \\
\text { ikaskuntza esanguratsua. }\end{array}$ \\
\hline & & $\begin{array}{l}\text { Agentzia (ahaldundu, baliabideak } \\
\text { eman, arriskuen aurrean prestatu) }\end{array}$ \\
\hline & & Segurtasuna, autokonfiantza \\
\hline & \multirow{2}{*}{$\begin{array}{l}\text { Aspektu sozio-emo- } \\
\text { zionala: taldekoa }\end{array}$} & Talde lana, kohesioa \\
\hline & & Generoaren trataera \\
\hline
\end{tabular}

Iturria: norberak eginikoa.

\section{III.- EMAITZAK}

\subsection{Erabilitako metodologia}

Bertsolari izateko moduei buruzko kontzientzia hartzea edo garai eta leku bakoitzean gertatzen denaz ohartzea da lehenengo pausoa eta, ondoren, metodologiaren eredu berriak bilatzea. Izan ere, bertsolaritza modernizatu aurretik zeuden bertsolari eredu bakarrak gizonezkoak ziren eta izaera maskulinoa zutenak gailentzen ziren kanon horretan, eztabaidarako ematen du zer den femeninoa eta zer maskulinoa. 
Ba, Lazkao Txiki baino... niri ez zait gustatzen esatea maskulinoa edo femeninoa ze adibidez, entzun izan dudalako «bai, bertso-eskoletan erakusten direla adjektibo maskulinoak, adibidez ausardia». Baina nola ausardia adjektibo maskulinoa da? Mesedez. Zer da hori, ezta? Baina bueno, horrela hitz eginda, Lazkao Txiki baino gauza femeninoagorik ez da egon. Sentibera zen. Ba hori neskekin beti izan da eta horregatik esaten du femeninoa. Aspaldiko kontua da hori, pare bat hamarkadako kontua da, hori bazegon, baina zergatik Txirrita hautatu eredu maskulino gisa? Ba, ez dakit, ez dakit. Beste arloa, seguraski, emakumeekin gehiago garatzen ari da, edo gehiago garatu nahi da behintzat (Berts5 20151203).

Baina emakumeen eredu edo erreferente ez hegemonikoen falta orokorra izan da, edonola ere fenomeno hau ez da gertatu bertsolaritzan bakarrik. Historian atzera eginda, oraindik ere gutxi daude, oraindik ekarpena da... Ze beti esaten da «emakumerik ez da egon». Jo, ba egon, egon dira, baina literaturan, antzerkian, pinturan gertatu den bezala ba desagertarazi egin direla. Esan nahi dut, ez da bertsolaritzaren esklusiba bat, hori gertatu da historian oro har. Orain zerbait aurkitu da dokumenturen batzuk edo... garai batean egon zirela, bertsoren bat edo beste. Gutxi dago, ezta? (Berts9 20160115).

Eremu guztietan emakumeak historiatik ezabatuak izan direla jakin arren, norberak bere esparruan ahalegin guztiak egin behar ditu gai horri buelta emateko.

\subsection{Aspektu sozio-emozionalaren zaintza (ikasle-irakasle)}

Gaur egungo irakasle batzuk kezkatuta daude emozioen kudeaketarekin, ikasleek bertsotan sufritu ez dezaten, eta eskura dituzten baliabideak erabiliz lantzen dute gaia, batez ere ikasleei segurtasuna ematen saiatzen dira.

Seguritatea transmititzekoak. Batez ere hori da, bera gustora sentitzea eta bera seguru sentitzea egiten duenarekin. Bera horrela sentitzen baldin bada, hori erakutsiko du. Bera ez bada horrela sentitzen, alperrik da, ez du disfrutatuko. Bueno, segurtasuna, hasteko nik uste dut norberak eduki behar duela transmititzeko bestela... bestela ez dago modurik (Berts5 20151203).

Horretarako, oso inportantea da ezagutzea nola sentitzen den ikaslea. Irakasleak talde-elkarrizketaren bidez ikasleak bultzatzen ditu sentimenduak kontziente egitera eta urduritasuna partekatzen dute eta hala ikusi ahal izan genuen behaketa egiterakoan.

Irakaslea 2: Nola sentitzen zarete kantatu aurretik, kantatzen duzuen bitartean eta ondoren?

Ikasle 1: Kantatu aurretik ondo, kantatu bitartean ondo...eta ondoren ondo.

Irakaslea 2: Bale, beste bat...esan.

Ikasle 2: Kantatu aurretik lasai, kantatu bitartean urduri.

Irakaslea 2: Aber zu... 
Ikasle 3: Kantatu aurretik urduri eta gogotsu, kantatu bitartean lasai...

Ikasle 4: Kantatu aurretik lasai, kantatu bitartean gogotsu eta ondoren...ondo.

Ikasle 5: Kantatu aurretik urduri, kantatu bitartean ez nuen ezer sentitu...eta ondoren lasai.

Ikasle 6: Kantatu aurretik oso-oso urduri, gero kantatu bitartean urduriago, eta geroago lasai.

(Behaketa_Irakasle 2)

Horren aurrean ahalegin handia egiten da erosotasuna lantzeko eta aukera bat baino gehiago ematen da bertsoak lasai eta gustura egin ahal izateko.

Eta saiatzen naiz hori egiten. Atera behar baditut banaka, adibidez, esaten: «bakoitzak nahi duen erritmoan hitz egingo du, aulki bat nahi duenak edo zutik nahi duenak, nahi duenak bizkarra emanda... ». Esan nahi dut gero gertatuko dira salbuespen horiek eta kasu askotan (Berts7 20160104).

Estrategia ezberdinak bilatzen dira lasaitasuna bilatzeko.

\subsubsection{Feedback}

Diskurtsoetan feedback-a zaintzen saiatu da. Segurtasunarekin batera autokonfiantza hitza agertzen da landu beharrekoen artean, izan ere, bi kontzeptu hauek oso gertu daude elkarrengandik. Zenbait ikasleri, nagusiki neskei, egokitu zaien genero rola dela eta, asko kostatzen zaie jendaurrean kantatzen hasteko urratsa ematea. Hala, batzuetan irakasleari psikologoaren papera egitea tokatzen zaiola aipatzen dute batek baino gehiagok.

Nik espreski ez dut landu konfiantza edo lotsa... Ba da zu konturatzea ikasle bakoitzak non fallatzen duen. Ba igual batek igual hizkuntzaren erabilera okerra, edo besteak denbora larregi hartzen du edo lehen esan dudan bezala, problema handiena zen belozidadea. Orduan oso perfekzionistak, orduan bertsotan ondo egiten dute, hizkuntza oso ondo landuta. Eta gero ba plazarako lotsa hori bai, orokorrean eduki ditut neskak beti bultzaka, bultzaka plazarako «benga, kantatu, joe kapaza zarela, benga ez duzula egingo txarto». Hori atzetik, psikologo papera... (Berts5 20151203).

\subsubsection{Agentzia}

Gaur egun, emakumeak ahalduntzeko eta bestelako gaiak lantzeko iniziatiba bat baino gehiago dago, batzuk ezagunagoak eta beste batzuk ezezagunagoak, baina bide ugari urratzen ari dira emakumeen bizitzak (ere) aintzat hartzeko, ikusgarri egiteko, eta esperientzia horiek plazaratzeko proposamena ailegatzen zaigu emakume bertsolarien eskutik. 
Itxaso Paiak dauzka bertso batzuk, ba, 'Begi Umelak', kontatzen du txikitatik berak futbolean ibili nahi zuela, amak esaten ziola ezetz, futbola ez zela neskentzako, eta horrelako gaiak mahai gainean jartzen ditugu (Berts 10 20160131).

Hori dela eta, elkarrizketatuek aipatzen dute, diskriminazio egoerez aritu behar direla esplizituki eta bertsolaritzaren munduko alde ilunez bertso-eskoletako klaseetan; ikasleekin hitz egin behar dela horretaz, norberak izan duen esperientzia partekatuz, eta gerta litezkeen une gozagaitzak mahai gaineratuz. Ikasleak prestatu behar dira gerorako eta bertsolaria izatea desmitifikatu behar da beraiekin.

$\mathrm{Ba}$, beraiek uste dutena bertsolaritzak eskainiko diena edo telebistan ikusten duten hori, ez dela dena. Eta nire krisi hori ba beraiei kontatzen diet inongo arazorik gabe. «Ba hau niri pasatzen zait hemen», beste hitz batzuekin klaro. Esan nahi dut dena ez dela polita eta ondo ibiliko zara bertso-eskoletan, eta ondo ibiliko zara eskolarteko txapelketetan eta gero ya bertsolaria izango zara eta telebistan aterako zara. Hasteko hitz egin beraiekin pila bat, eta gero generoaren gaian sartzen saiatzen naiz, klaro (Berts10 20160131).

Nesken kasuan bereziki hezkuntza sexistaren ondorioz ikasi duten apaltasuna dela medio, oholtzara igotzeko bultzatu beharra dago, lotsa gainditzeko eta aurrera egiteko ahaldundu behar dira, seguru eta konfiantzaz egin dezaten aurrera. Haiek erabaki ahal izateko zer nahi duten egin taula gainean eta zer ez.

Orduan bueno ikasleei esaten «zu holakoa baldin bazea, holakoa izan, baina kontuan izan aspektu gehiago ere badaudela eta zure erronka pertsonala izango da zu noraino biluztu edo ez, edo nahi duzun landu edo ez».Erakutsi behintzat pixka bat ba esparru asko daudela(Berts8 20160109).

\subsubsection{Segurtasuna, autokonfiantza}

Aipatutako guztiagatik, lehiaketaren aurrean umeek beldurra pasatzen dutela argi dago, egoera gogorra izaten da jendaurrekoa, eta bereziki hasieran, umetan. Hori dela eta, horretarako prestakuntza emozionala ezinbestekoa da. Elkarrizketatutakoen arabera oraindik hutsune emozional asko ikusten dira lehiaketetan, batez ere, umeen artean, ez zaie erakutsi nola kudeatu sentimenduak.

Eta ni sekula ez naiz damutu nire umeak eraman izanaz inoiz ez zaidalako ume bat bertso erdian geratu negarrez. Baina nik ikusi ditut hor barbaridadeak, irakasleei bi belarrondoko emateko modukoak. «12-13 urteko ume bat hor negarrez?». Eta gainera itxaron behar du beste bi talde kantatu bitartean beste ordu erdi, eta zuk ezin duzu joan, ezin diozu besarkada bat eman, ezin duzu lasaitu momentuan. Eta ume batzuei esan behar zaie «oraindik ez zaude prest ateratzeko» eta beste batzutan esan behar zaie kontrakoa «benga, gai zea 
hori eta gehiago egiteko». Jo es ke batzuk, «nik egingo dut, nik egingo dut». Bai eta gero? Han denak umiltzen dira, harroena ere umildu egiten da hor (Berts8 20160109).

Klaseetan oholtzarako prestatzen dituzte ikasleak, simulazioak egiten dira. Emozioei buruz hitz eginda, haien eraginei erreparatuta, lanketa emozionala bertsoen bidez egiten dute.

Irakaslea 1: Oso ondo. Orain botako dozue bakoitzak zortziko txikia bana. Bai, ezta? Orduen bakoitzari emongo dotzuet emozino bat. Orduen deskribatu beharko dozue egoera bat esan barik zein dan hemengo hitza, baina emozino hori sentitu duzuena edo sentitu leikena beste batek. Eta batek kantauko dau eta besteak asmau.

Ikasle 1: emozinoa zein dan...

Irakaslea 1: emozinoe zein dan. Bale? Edo koplatan. Orduen bakoitzak bat, deskribatu biozue. Zortziko txikia edo nahi dozuena. Egoera bat zuek sentitu duzuena...

(Irakaslea 1)

Konfiantza eta segurtasuna lantzeko, irakasleak erantzun edo errefortzu positiboak eta zuzenketa esanguratsuak ematen saiatzen dira.

Ikasle 1: (neurri bat botatzen du) egia esan ez zait batere gustatzen elurra.

Irakaslea 1: Aber, aber, neurrixe hori. Egia esan ez zait batere gustatzen elurra. Hor zeozer faltatzen da. Benga, bota.

Ikasle 1: ez da ona niretzako eta gainera ez da ziurra, egia esan ez zait batere gustatzen niri elurra.

Irakaslea 1: oso ondo, primeran!

Ikaslea 1: zapatu gaba dugu goizeko bostetan. Abadiñotik bueltan etxeratzekotan. Pausuek entzun dodaz nik neu hortxe bertan. Ni korrika hasi naiz urduri benetan.

Irakaslea 1: Urduri benetan. Earra, Irune!!!

(Irakasle 1)

\subsection{Aspektu sozio-emozionalaren zaintza (taldekoa)}

\subsubsection{Talde lana, kohesioa}

Bakarkako lana egiten da, baina taldeka ere ariketa asko egiten dira. Irakasleek hainbat jardueratan talde lana proposatzen dute, adibidez asmakizunak sortzea elkarrentzat. 
Hirukotea: Etxera ailegatzean ikusi nuen, bertan egoten dira, argazkiak ere, sagua-teklatua, behar ditu ere, zer egingo genuke gu tresna hau gabe.

Ikasle bat: ordenagailua.

Irakaslea 2: bai, orain beste bat.

(Irakasle 2)

Bertsoak taldeka egiten dituzte, irakasleak oinak emanez taldeka osatzen dituzte proposaturiko ariketak. Talde bakoitzak gertaera desberdinak baloratuko ditu, tartean, emozioak ere adieraziz.

Talde 1: Bukatu da ikastola, nolako pasada.

Azterketa guztiak, bota begirada.

Oso estresatuta gu ibili gara,

oso ondo pasata gozatu udara.

(Irakasle2)

Taldean hortik kanpo bizitako esperientzia adierazgarriak konpartitzen dituzte, leku berezi hori dute bertso klaseetan. Elkar ezagutzeko, taldea egiteko, eta enpatizatzeko balio duten pasarteak.

Ikasle 1: Ba...zelan da? Gabonetan, bueno, barnetegi modukoan zeuden bi Iparraldeko neska eta harrapatu nituen kanta hau abesten. Ba gustatu zitzaidan asko doinua, ba azkenean ikasi genuen danok. Eta oso polite da eta letrie bebai eta... ba horregatik aukeratu dut. Letra da, eskertzeko moduen amari. Ze bera barik ez ginen egongo hemen, hori bakarrik.

Ikasle 2: ondo. Kantatuko dugu?

Irakasle 4: Bale orduen zer egingo dugu, bideoa ikusi?

Ikasle 1: bai, ez?

(Irakasle4)

\subsubsection{Generoaren trataera}

Bukatzeko, generoaren gaia klaseetara eramaten da, irakasleak planteatzen du eta taldeka hausnartzen dute egungo jendartean gertatzen diren diskriminazio eta injustiziei buruz ikasleek pentsamendu kritikoa gara dezaten, iritzi propioa osatu dezaten.

Irakasle 1: ...zauritu eta gero neska bat bortxatu dute Santutxun...hori...zergaitik ez dugu jarri...pentsau...Lau aste barru eta askotan egoten da eztabaidie genero indarkeria esaten dana; eztabaidi egoten da batzuk kontsideratzen dabielako hori bakarrik dala bikote harremanien danean. Eta batzutan eztabaidie egoten da. Baina ez da kasualidadie beti erasotzen dauena...zer da beti? 
Ikasle guztiak: Gizona.

Irakaslea 1: Eta beti erasoa jaso duena andrie. Orduen genero indarkeria ez da bakarrik bikotie. Orduen aber zer...zer...zer uste duzue? Zelan ikusten duzue asuntue?

Ikasle 1: Txarto

Ikasle 2: Gertatzen dela behin eta berriro.

(Irakasle1).

Horrela, gizartean ematen diren diskriminazoak mahai gaineratzen dira egungo klaseetan, ikasleek gai honi buruz kontzientzia hartu dezaten eta esperientzia horiek ahalduntzerako bidean lagundu dezaten, neska-mutilek haien genero-rolak desikasi eta nortasun propio aske eta berdinzalea eraiki dezaten.

\section{IV.- ONDORIOAK}

Bertso-eskolen ibilbideko hasierako bertsolaritzaren irakaskuntza eredutik gaur egungo eredura garapen handiena izan duena adimen emozionalaren lanketa izan da, izan ere, duela 30-40 urte hori ez baitzen jorratzen, askotan, bertsolari-eredua oso maskulinoa izanda, emakumeek jendaurreko bat-bateko bertsolaritza uzten zuten gaizki pasatzen zutelako jarrera mesfidatia zuen publiko baten aurrean emozioak ezkutatzen eta segurtasun eza sentitzen zutelako. Izan ere, duela gutxi arte, emozioen kudeaketari eta ikuspegi feministari ez zitzaien inongo garrantzirik ematen eta autokonfiantza eta egoeraren irakurketa kritikoa ez ziren ikasketa prozesuan presente egoten. Beraz, presio sozialarekin ezin zuenak bertsolaritza uzten zuen (Alberdi 2015; Lasarte + Vizcarra + Perales + Fernández 2020: 258).

Alde batetik, azpimarratu daiteke alde emozionalaren garrantzia, oholtzarako prestaketa egiten da segurtasuna izateko edo askatasunez adierazteko, eta horretarako autoestimua eta autokonfiantza garatzen dira ikasle guztien artean (Lanku 2008: 57). Ariketak egiten dira momentu bakoitzean sentitzen diren emozioei izena jartzeko. Kontzientziazio momentu horretan emozio horiek bideratzen ikasten dute (Fragoso 2015: 120) eta hori horrela eginda, bide aproposa izango lukete ikasleek bertsogintzan automotibaziora ailegatzeko (Goleman, 1996). Konfiantza eta segurtasuna bermatzen dira adimen emozionalaren lanketaren bidez eta ikasleak ekintza burutzeko gai direla jabetzen dira, sufrimendu gabe eta gozatuz, irakasleen laguntzari esker (Printich + De Groot 1990: 33).

Jendaurrekotasunak pisu handia dauka bertsolari(gai) bakoitzaren jardunean, oraindik hutsune emozionalak ikusten baitira lehiaketetan (urduritasuna, beldurra, segurtasun falta, mina). Diskurtsoak koherentzia izan dezan eta ikasleek ahalik eta erosoen kanta dezaten irakaslea hor egoten da beti, oholtzarako prestatzen ditu ikasleak. Irakasleak feedback positiboak eta zuzentzaileak erabiltzen ditu diskurtsoek eta praktikek oreka izan dezaten (Lanku 2008: 57). 
Beste alde batetik, ezin da ahaztu testuinguruaren garrantzia, bertsolariak publikoari kantatzen diolako eta hau ez da beti aldeko jarrerarekin egoten. Hori dela eta, taldeka ariketa asko egiten dira, jarduera dialogiko eta interaktibo asko proposatzen dira; bertsolaritza talde lana lez ulertu behar da eta (Sarasua 2007: 35). Bertso-saioak elkarreraginean eraikitzen dituzte bertsolariek, ahaztu gabe testuingurua kontuan izan behar dutela eta publikoarengana ailegatu behar direla haien bertsoak (Garzia + Sarasua + Egaña 2001: 143).

Enpatiak leku berezia du jarduera horretan, izan ere, sentimenduen truke horretan bakoitzaren ikuspuntua zein den ahaztu gabe besteena ulertzeko gai izan behar dira (Bisquerra 2011:67). Taldekideek esperientziak partekatzen dituzte eta gai desberdinei buruz hausnartzen dute elkarrekin; horrek guztiak eragina du bertsolarien diskurtso eta praktiketan eta talde izaera indartzen laguntzen du, ikasle bakoitzak taldearen babesa senti dezan (Artetxe 2019: 259).

Egun bertsolaritzaren esparru formal eta ez formaletan genero perspektiba txertatu da, eta behatu den bezala, pertsona kontzientziadunek (Alberdi, 2019) aurrera eramaten dute bertsolaritzaren irakaskuntza, zein bertsotan trebatzeko tokia izateaz gain, hausnarketarako lekua ere bihurtu den (Artetxe 2019: 257). Irakasleak planteatzen du hausnarketa kritikoa, injustiziei eta diskriminazioei aurre egiteko xedearekin, jendartean dagoen ikuspegi androzentriko hori salatze aldera.

Bertsolaritzaren irakaskuntzaren alorrean dihardutenak kontziente dira bertsolari emozionalki konpetenteak behar direla oholtzan eta bertsolaritzan dagoen lehiakortasunari aurre egiteko funtsezkoa dela arrazoi eta argudioez harago joatea eta sentimenduak aintzat hartzea klasean (Lasarte + Alvarez-Uria + Ugalde + Lekue + Martinez 2016:150). Ezinbestekoa da trebetasun pertsonalak eta sozialak lantzea eta garatzea hortaz, eta puntu horretan lanean dihardute bertso-eskoletan eta hezkuntza arautuan, elkarrizketatu ditugun emakume bertsolari-irakasleek esandakoak kontuan izanda.

Autoezagutzari indar handia ematen ari zaio beraz. Ezinbestekoa da emozio bat agertzen den momentuan hura detektatzea, emozio hori ondo bideratu ahal izateko. Egungo irakasleek alde teknikoa zein sozio-emozionala irudikatzen dituzte gaurko bertsolari erreferenteetan. Horrela, bidenabar, ikasleen konpetentzia pertsonala lantzen ari da (Gardner 1993; Goleman 1996). Horretarako oso garrantzitsuak dira irakaslearen lana eta honek erabilitako metodologia: feedback positiboa eta zuzentzailea erabiltzea inportantea da, ikasle-irakasle harreman dialektikoa sustatu behar du, arriskuen aurrean gai izateko prestatu behar ditu ikasleak, eta talde izaera indartu behar du, besteak beste.

Gero eta aniztasun handiagoa dago bertsolarien estilo eta bertsotarako gaietan. Emakume erreferente garrantzitsuak daude eta emakumeen bizi-esperientziak gero eta ohikoagoak dira bat-bateko jardunean. Hala ere, diskriminazio eta zapalketei buruz hitz egiten eta hausnarketara bultzatzen jarraitu behar da (Downing + Roush 1985: 706). Bertsolaritza kultur adierazpena eta praktika soziala izanik ez baitago botere harreman eta bereizkeriez libre. Espazio sozialak garai bakoitzeko gizarte-sistema erreproduzitzeko joera du, eta urteetan eman diren genero estereotipoen kontra aritzea prozesu neketsua da; gure inguruan dagoen guztia egon daiteke estereotipoekin kutsatuta. 
Esan daiteke, bertso-plaza, bertsokerak edo bertso-moldea eredu hegemonikoaren hizkuntzan eta estereotipoekin muntatu dela ( Lasarte + Álvarez-Uria + Ugalde + Lekue + Martinez 2016: 159). Egungo hezitzaileek ezinbestekoa dute praktika diskriminatzaile, sexista eta baztertzaileetatik urruntzea. Horrela, hezkuntzak jarraitzen du modu kritikoan hausnartzen, oraindik bizi-bizirik jarraitzen du androzentrismoak rol femenino eta maskulinoaren irudikapenean. Lanketa hau guztion lanketa da, harreman, estereotipo, rol patriarkaletik aldentzen bai emakume, bai gizon, bai bertsolari, bai bertsozale, bai pertsona guztien lana delako.

Esan genezake emakume bertsolariak emakumeen subordinazioa dagoela konturatu direla eta horren kontzientzia hartu dute (Lasarte + Ugalde + AlvarezUria + Martinez 2019: 41), eta hortaz aldaketarako aukera ikusi dute haien bizipenak partekatuz eta egunerokotasunean ikasitakoa erabiliz, ikasle guztiak ahalduntzeko eta agente aktibo bihurtzeko bide horretan. Puntu honetan agentzia praktika soziala eta pertsonala dela uler daiteke (Lasarte + Vizcarra + Perales + Fernández 2020: 253).

Baina bertsolaritza ez da bertsolariaren bakarkako lana soilik, testuinguruaren eragina aipatzen baita behin eta berriro. Bertsokideen arteko enpatia sustatzea da egungo helburuetako bat, horri esker, besteen ikuspuntua ulertzeko (Bisquerra 2011: 67) konpetentzia soziala lantzen saiatzen dira eskoletan. Egungo irakasleek argi dute talde lana ezinbestekoa dela adimen emozional interpertsonala edo erlazio gaitasunak garatzeko (Betancourth + Zambrano + Ceballos + Benavides + Villota 2017:134) ahaztu gabe bertsolariak publikoarekin batera osatzen duela bertsoa, baina hartzailearen rolari eta eraginari buruz beste batean hitz egingo dugu.

Laburbilduz, lan honekin ekarpentxo bat egin nahi izan da bertsoa irakasten den lekuetara hurbiltzeko ahalegina eginez. Egungo irakasleek metodologia propioa eraiki dute eta esan daiteke, ikuspegi dialogiko, kritiko, berritzaile eta inklusiboa hedatzen ari dela. Zalantzarik gabe, eredu tradizional batetik abiatuta emakume bertsolari-irakasle horiek egindako hausnarketei eta ahalegin esker emozioen lanketari leku berezia egin diote, pertsonaren osotasuna ahazten ez duen metodologia erabiliz. Azken finean, denontzako lekua eginez gure bertso-eskoletan.

\section{V.-BIBLIOGRAFIA}

Alberdi, U. (2015) Bertsolaritza eta generoa, Errenteria, Memorandra aurkezpena.

Alberdi, U. (2019) Kontrako eztarritik. Emakume bertsolarien testigantzak, Zarautz, Susa.

Alviárez, L. + Pérez, M. (2009) «Inteligencia emocional en las relaciones académicas profesor-estudiante en el escenario universitario», Laurus, 30, pp. 94-117.

Amuriza, X. (1982) Zu ere bertsolari, Donostia, Elkar. 
Artetxe, M. (2014) «Bertsolaritzaren eragina Lapurdiko bertso-eskoletako gazteen identitatean eta hizkuntza erabileran», BAT Soziolinguistika Aldizkaria, 92, pp. 11-31.

Artetxe, M. (2019) Emakume bertsolari garaikideak. Ahalduntze-prozesu baten kontaketa posible bat, Bertsolaritza feminismotik (bir)pentsatzen, Bilbao, Udako Euskal Unibertsitatea.

Betancourth, S. + Zambrano, C. + Ceballos, A. + Benavides, V. + Villota, N. (2017) «Habilidades sociales relacionadas con el proceso de comunicación en una muestra de adolescentes», Revista Psicoespacios, 18, pp.133-148.

Bisquerra, R. (2003) «Educación emocional y competencias básicas para la vida», Revista de Investigación Educativa, 1, pp. 7-43.

Bisquerra, R. (2011) Educación emocional. Propuestas para educadores y familias, Bilbao, Desclée de Brower.

Coffey, A. + Atkinson, P. (2003) Encontrar el sentido a los datos cualitativos, Medellin, Contus.

Downing, N. + Roush, K. (1985) «From passive acceptance to active commitment: A model of feminist identity development for women», The Counseling Psychologist, 13, pp. 695-709.

Esteban, M. (2019), Begirada bat bertsolaritzari feminismotik, Bertsolaritza feminismotik (bir)pentsatzen, Bilbao, Udako Euskal Unibertsitatea.

Flick, U. (2014) El diseño de la Investigación cualitativa, Madril, Morata.

Fragoso, R. (2015) «Inteligencia emocional y competencias emocionales en educación superior, ¿un mismo concepto?», Revista Iberoamericana de educación superior, 16, pp. 110-125.

Flores, E. + Garcia, M. + Calsina, W. + Yapuchura, A. (2016) «Las habilidades sociales y la comunicación interpersonal de los estudiantes de la Universidad Nacional del Altiplano - Puno», Comuni@ @ción, 7, pp. 5-14.

Gardner, H. (1993) Multiple Intelligences: The Theory and Practice, New York, Basic Books.

Garzia, J. + Sarasua, J. + Egaña, A. (2001) The Art of Bertsolaritza: improvised Basque verse singing, Donostia, Euskal Herriko Bertsozale Elkartea.

Goetz, J. + Lecompte, M. (1988) Etnografía y diseño cualitativo en investigación educativa, Madril, Morata.

Goleman, D. (1996) Emotional Intelligence, New York, Bantam books.

Haardep, + Gowda, P. (2019) «Emotional intelligence for better self-perception of social ability», International Journal of Research and Analytical Reviews, 1, pp. 990-993.

Lanku. (2008) Bertsolaritzaren Curriculuma Lehen hezkuntzan, Villabona, Euskal Herriko Bertsozale Elkartea. 
Larrañaga, J. (2013) Jolas sakona: Txapelketaren prozesu errituala eta bertsolariaren arrazoi sortzailea XXI mendeko agoran, Bilbo, Euskal Herriko Unibertsitatea.

Lasarte, G. + Álvarez-Uria, A. + Ugalde, A. + Lekue, P. + Martinez, J. (2016) Emakume bertsolariak. Ahanzturatik diskurtso propiora, Gasteiz, Emakunde.

Lasarte, G., Ugalde, A., Alvarez-Uria, A., \& Martinez, J. (2019) «Emakume bertsolariak ezagutzen», Uztaro, 110, pp. 39-60.

Lasarte, G.+ Fernández, V. + Alvarez-Uria, A. + Gómez-Pintado, A. (2019) «Women bertsolaris, reclaming the past, singing the present», Prisma Social, 25, pp. 488-518.

Lasarte, G. + Vizcarra, M. + Perales, A. + Fernández, V. (2020) «Las mujeres bertsolaris, agentes en su incorporación a la escena pública», Boletín de Literatura Oral, 10, pp. 249-264.

Losada, L. (2018) «Reflexión y construcción del conocimiento en torno a las habilidades sociales y la competencia social», RECIE. Revista Caribeña De Investigación Educativa, 2, pp. 7-22.

Lujanbio, M. (2019) Arbola hazten, azala zartatzen. Azken 40 urteak bertsolaritzan: bertso-eskolaren sorrera eta emakumeen sarrera, Bertsolaritza feminismotik (bir)pentsatzen, Bilbao, Udako Euskal Unibertsitatea.

Moi, T. (1989) Feminist, female, femenine, The Feminist reader, Basil Blackwell, New York.

Printrich, P. + De Groot, A. (1990) «Motivational and self-regulated learning components of classroom academic perfomance», Journal of Educational Psychology, 82, pp. 33-40.

Rekalde, I. + Vizcarra, M. + Macazaga, A. (2014) «La observación como estrategia de investigación para construir contextos de aprendizaje y fomentar procesos participativos», Educación XX1, 17, pp. 199-220.

Rodríguez, G. + Gil, J. + Garcia, E. (1996) Análisis de los datos cualitativos asistidos por ordenador: aquad y Nudist, Bartzelona, PPU.

Salovey, P. + Mayer, J. D. (1990) «Emotional intelligence», Imagination, Cognition, and Personality, 9, pp. 185-211.

Sarasua, J. (2007) «Social Features of Bertsolaritza», Oral tradition Journal, 22 , pp. 33-46.

Soroa, N. (2010) «Abiatu beharko genuke ikasle bakoitzak dauzkan ezaugarrietatik», Bertsolari Aldizkaria, 78, pp. 18-33.

Vallés, M. (2003) Técnicas cualitativas de investigación social, Madril, Síntesis Sociología.

Zubiri, H. + Aierdi, X. + Retortillo, A. (2019) Kultura ez da bat-batekoa. Bertsolaritza aztergai, Bilbo, Euskal Herriko Unibertsitatea. 